\title{
Notes
}

\section{A "living" will}

I met Edward at the end of his life, during a palliative medicine rotation. He was barely rousable and unable to communicate; I came to know him only through the words of his hospital chart and from speaking to his sisterin-law. Edward had left school early and served during World War II in the Royal Canadian Air Force as a bomb aimer. After the war, he worked as a postal worker for 35 years, and was an avid gardener and photographer, particular of nature scenes. Married for 48 years, with no children, he was widowed I2 years ago. At the age of 87 , he was still living on his own and had been independent up until the last few months, when he gradually became weaker and eventually needed hospital admission. Appropriate tests were ordered, and they showed metastatic lesions in his liver, lungs and several vertebrae.

With his input, no further investigation or treatment occurred, and the medical team initiated compassionate care. Our service was consulted for as-
To My Family, My Physician, My Lawyer, My Clergyman,

To Any Medical Facility in whose care I happen to be,

To Any Individual who may become responsible for my health, welfare or affairs,

Death is as much a reality as birth, growth, maturity and old age - it is the one certainty of life. If the time comes when I, Edward R. Smith can no longer take part

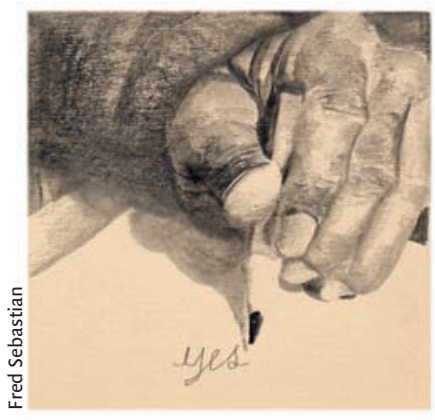
in decisions for my own future, let this statement stand as an expression of my wishes while I am still of sound mind.

If the situation should arise in which there is no reasonable expectation of my recovery from physical or mental disability, I request that I be allowed to die and not be kept alive by artificial means or "heroic measures." I do not fear death itself as much as the indignities of deterioration, dependence and hopeless pain. I, therefore, ask that medication be mercifully administered to me to alleviate suffering even though this may hasten the moment of death.

This request is made after careful consideration. I hope you who care for me will feel morally bound to follow its mandate. I recognize that this appears to place a heavy responsibility upon you, but it is with the intention of relieving you of such responsibility and of placing it upon myself in accordance with my strong convictions, that this statement is made. sessment for hospice placement. When he had declined to the point where the hospice would not offer him any additional quality of life, this information was shared with his sister-in-law. She mentioned that she had provided a copy of his living will for his chart.

What I found was not only a standard living will, but insight into Edward's views on life, death, infirmity and the burden of illness on family. Unlike many of today's legally prepared documents, Edward's document was simple, succinct, but also eloquent and heartfelt; it portrayed his deep personal conviction on end-of-life issues. It was not a will from someone with formal writing experience, but someone with life experience. After reading what he had prepared, I felt that I had come to understand who Edward really was; even though I could not speak with him.

With his family's permission, his living will is reprinted here.

\section{Mark Belletrutti MD}

Fellow, Pediatric Hematology,

Oncology, Palliative Care

Stollery Children's Hospital

Edmonton, Alta.

Ingrid DeKock MD MBChB

Regional Palliative Care Program

Grey Nuns Community Hospital

Edmonton, Alta.

For confidentiality reasons, the patient's name has been changed. The patient's family has given permission for this will to be adapted for use by others. 